\title{
ПАМЯТИ ИВАНА ПАВЛОВИЧА ДЕЙНЕКО
}

\author{
$(13.12 .1944-25.11 .2015)$
}

Лесные химики страны понесли тяжелую утрату. 25 ноября 2015 г. на 71-м году жизни скончался талантливый педагог, заслуженный преподаватель высшей школы, ученый, профессор Санкт-Петербургской лесотехнической академии, университета растительных полимеров, доктор химических наук, член-корреспондент РАЕН Иван Павлович Дейнеко.

Иван Павлович родился 13 декабря 1944 г. в Ленинграде. Окончил Ленинградскую лесотехническую академию в 1972 г. С 1967 г. работал в Лесотехнической академии. Механик, инженер, младший научный сотрудник, старший научный сотрудник, доцент, профессор, специалист в области химии древесины.

И.П. Дейнеко разработал теоретические представления о химических реакциях лигнина при делигнификации древесины с участием кислорода, изучал кислотнокаталитические превращения древесины, занимался получением катионообменных сорбентов из древесного сырья, изучал экстрактивные вещества коры сосны, ели, осины, ивы. Он автор более 150 научных трудов. Значи-

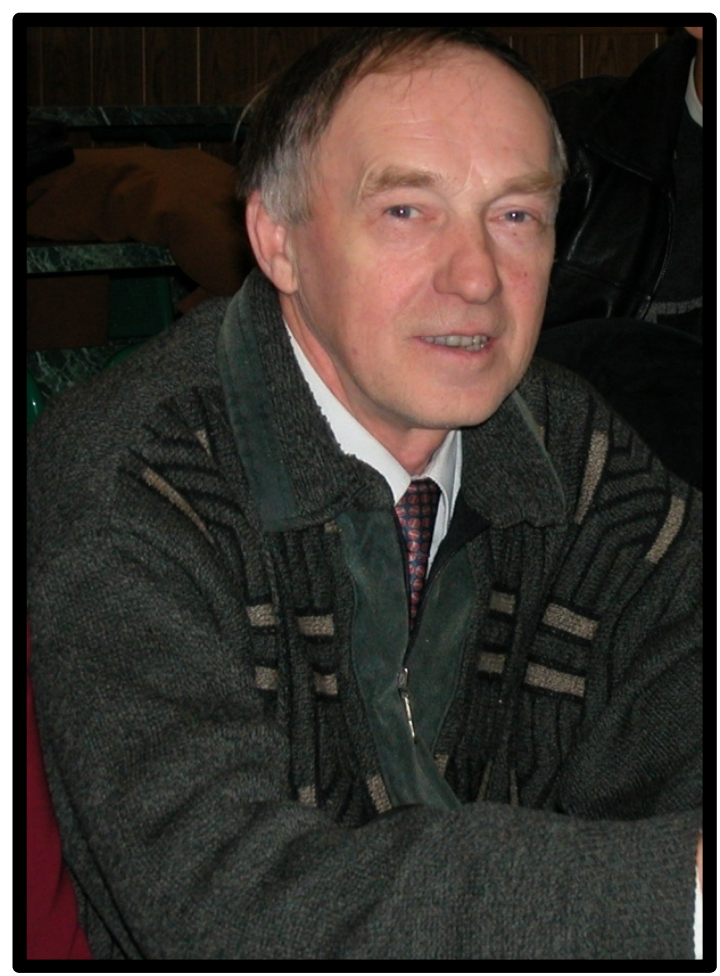
тельная часть «Нового справочника химика-технолога. Сырье и продукты промышленности органических и неорганических веществ» создана И.П. Дейнеко. В любой работе Ивана Павловича отличала высочайшая методичность и требовательность к себе и своим ученикам в подготовке и выполнении экспериментов, написании научных трудов.

Научно-исследовательская работа профессора И.П. Дейнеко была тесно связана с подготовкой высококвалифицированных кадров. Под его руководством защитили диссертации специалисты в области химии, лесохимии, химии древесины и целлюлозы, будущие преподаватели, исследователи, научные работники: С.Н. Никольский, С.И. Колотов, А.Б. Никандров, Н.Г. Костюкевич, Д.В. Евтюгин, Т.Г. Федулина, О.В. Макарова, М.Ю. Балакшин, Д.Н. Ведерников, И.В. Корбукова, Н.М. Фаустова.

Иван Павлович Дейнеко принимал активное участие в работе редакционной коллегии журнала «Химия растительного сырья».

Коллеги, ученики, друзья и родные скорбят о кончине Ивана Павловича. Светлая память об Ученом, Учителе навсегда сохранится в наших сердцах.

Члены редакционной коллегии журнала

«Химия растительного сырья»,

друзья, коллеги, ученики 
